\title{
The family tree - a challenge for multicultural learning: some aspects of Swedish, Serbian and Bulgarian kinship terminology
}

\section{Sabira Ståhlberg}

Independent scholar, E-mail: sabirien (at) pm.me

\author{
Dorijan Hajdu
}

\author{
University of Belgrade, \\ E-mail: dorijan.hajdu (at) fil.bg.ac.rs
}

\begin{abstract}
To discover the essential differences in cultural and linguistic patterns of a certain society, we need to look no further than to the most common relations of all - those between family members. When studying, working and living in, or for instance marrying into another culture, we must not only learn, but also acquire and utilise a whole new set of relationships and terms in order to be able to function and communicate. Without this knowledge we will quickly encounter a multitude of social difficulties in the other environment. On a deeper level, if we follow the assumption that a language is the mirror of its culture, and that language also influences culture, the linguistic terms designating family relations present a number of interesting phenomena, such as: which relations occupy the centre of importance in the society; the concept and understanding of a core family; which family relations are considered "worth" having a term for, and thus meaningful to keep up; the relations after a crisis, for instance a divorce; and several more, including the transfer of family relations to friendship and business contacts.
\end{abstract}

This qualitative pilot study discusses some important aspects of family relations from the perspectives of Swedish-language (Sweden and Swedish-speakers in Finland) family terminology, in comparison with Serbian and

\section{Rezumat}

Pentru a identifica diferențele esențiale dintre modelele culturale și lingvistice ale unei anumite societăți, nu trebuie să ne uităm mai departe decât la cele mai obișnuite relații - cele dintre membrii familiei. Când studiem, lucrăm și trăim, sau de exemplu ne căsătorim într-o altă cultură, nu trebuie doar să învățăm, ci și să dobândim și să folosim un set complet nou de relații și termeni pentru a putea funcționa și comunica. Fără aceste cunoștințe ne vom confrunta rapid cu o multitudine de dificultăți sociale în mediul de inserție. La un nivel mai profund, dacă pornim de la premisa că o limbă este oglinda culturii sale, iar limba influențează și cultura, termenii lingvistici care desemnează relațiile de familie prezintă o serie de fenomene interesante, precum: ce relații ocupă poziția centrală în societate; conceptul și înțelegerea familiei de bază; care relații de familie sunt considerate a avea "meritul" pentru a le fi alocat un termen specific și care sunt, prin urmare, important de întreținut; relațiile după o criză, de exemplu un divorț; și multe altele, inclusiv transferul relaţiilor de familie la prietenie și contacte de afaceri.

Acest studiu pilot calitativ abordează câteva aspecte importante ale relațiilor de familie din perspectiva terminologiei familiei în limba suedeză (Suedia și vorbitorii de suedeză în Finlanda), în comparație cu limbile sârbă și 
Bulgarian. The study also includes a Serbianlanguage survey about kinship terms, and it raises questions about further research into cultural and social patterns and connotations reflected in kinship terminology. Social and cultural differences specifically between the Serbian and Swedish spheres are highlighted; the Bulgarian and Swedish-speaking terminologies in Finland are used here mainly as references and for comparative purposes. The study combines different scientific fields in mapping out some aspects of cognitive, social and cultural patterns. It emphasises the importance and necessity of multilingual and multicultural learning instead of foreign language and culture learning, and shows some of the pitfalls and possibilities students of languages and cultures encounter when learning new kinship concepts and terms. bulgară. Studiul include, de asemenea, un sondaj în limba sârbă despre termenii de rudenie și ridică o serie de întrebări pentru cercetări ulterioare privind modelele și conotațiile culturale și sociale reflectate în terminologia de rudenie. Sunt evidențiate diferențele sociale și culturale, în special între limba sârbă și cea suedeză; terminologiile de limbă bulgară și suedeză din Finlanda sunt folosite aici în principal ca referințe și în scopuri comparative. Studiul combină diferite domenii științifice pentru cartografierea unor aspecte ale modelelor cognitive, sociale și culturale. Acesta subliniază importanța și necesitatea învățării multilingve și multiculturale în locul învățării limbilor și culturii străine, și arată unele dintre capcanele și posibilitățile pe care le întâmpină cei care studiază limbile și culturile atunci când învață concepte și termeni noi de rudenie.

Keywords: Bulgarian, cultural comparison, cultural patterns, family structures, FinlandSwedish, kinship terminology, language learning, multicultural learning, multilingual learning, Serbian, Swedish

\section{BY-SA License (https://creativecommons.org/licenses/by-sa/2.0)}

This paper has been presented at the Twelve International Conference on Baltic and Nordic Studies in Romania: ReThinking multiculturalism, multilingualism and cultural diplomacy in Scandinavia and the Baltic Sea Region, hosted by the Romanian Association for Baltic and Nordic Studies, May 27-28, 2021.

\section{Introduction}

To discover essential similarities or differences in cultural and linguistic patterns present in a certain society, it is sufficient to look into the most common relations of all human connections - those of family and kinship. For more than a century, anthropologists, ethnologists, sociologists, historians and scholars from several other fields have studied extensively family structures and relationships between its members, relatives, and persons who are not related by blood, but for social reasons are considered part of the family. Researchers have so far shown a keen interest in how intrinsic social relations are created, constructed, maintained and developed, and they also observe the consequences of kinship connections, for instance on marriage. The selection of partners and the question who could be an eligible spouse is of crucial importance for all human societies. 
A large part of the existing kinship literature ${ }^{1}$ is concerned with regions and peoples outside the Western European and North American contexts. WEIRD (Western, Educated, Industrialised, Rich, Democratic) theories, terms, concepts and definitions have however been applied impartially to many non-WEIRD societies (in fact, the majority of all societies in the world), where they have little significance or are simply misplaced. ${ }^{2}$ Further, academic publications discussing kinship mainly present case studies focusing on singular groups, who are overtly and consciously, or less perceptively and covertly compared with Western European or North American societies, and commonly viewed through the lens of Western science.

Only in the second half of the twentieth century, criticism followed upon the earlier studies concerning descent, lineages, marriages, alliances, clans and other aspects of kinship, calling for a more adequate terminology and a less biased view. Still, scientific efforts to categorise and map out kinship terms and relations are seriously challenged by the reality and a great variety of understandings, views and flexibility of kinship relations even within one region, cultural sphere or society. This is visible even in intra-European studies such as "Balkan kinship models". ${ }^{3}$ There is no such thing as a common Balkan model; it is an academic construction and overgeneralisation. Indeed, the fairly close Serbian and Bulgarian kinship terms and concepts presented in this article contain several important differences.

The topic of learning kinship systems and terminology is naturally crucial for students of languages and cultures, but it is also essential for translators and researchers. Multilingual and multicultural learning is in fact an important key to other cultures and societies for all who travel, move from

\footnotetext{
${ }^{1}$ A theoretical discussion on kinship is outside the scope of this article, and the statements here refer to the existing literature in general.

2 See Joseph Henrichs, The WEIRDest people of the world (New York: Farrar, Straus and Giroux, 2020); and the earlier article by Joseph Henrichs, Steven J. Heine and Ara Norenzayan, "The weirdest people in the world?" Behavioral And Brain Sciences 33 (2010): 61-135.

${ }^{3}$ For history on traditional family structures in the Balkans, see for instance Maria N. Todorova, Balkan family structure and the European pattern. Demographic developments in Ottoman Bulgaria (Budapest: Central European University Press, 2006. Original 1993); Ulf Brunnbauer, "Unity in Diversity? Historic Family Forms in Southeastern Europe", Historijski Zbornik god. LXV, br. 1 (2012): 95-148.
} 
one country to another, work outside their childhood language and cultural context, or in general relate with people from different backgrounds. To avoid the biggest pitfalls - and in our experience they are numerous - it is important to know not only one's own kinship system and terminology, but also to understand, gain more knowledge of and be able to adapt to, utilise and in general navigate within other kinship systems in an increasingly globalised world.

Especially when marrying or having a partner from another culture, the need to learn how the other kinship system functions becomes not only urgent, but critical. The individual ${ }^{4}$ must acquire a whole new set of relationships and terms, and simultaneously balance between the two (or more) cultures: the spouse's family and cultural patterns, habits, principles and inclinations on one side, and the individual's own traditions, values and personal preferences on the other. This first phase, before the individual and the family have found or created a joint working or co-existence mode, can be extremely stressful, and ultimately contribute to make the marriage or partnership stronger - or destroy it. The capacity of identifying correctly the positions and roles of the partner's or spouse's family members and kin, using the kinship terminology in their way, and adapting at least to a certain extent to their behavioural patterns, facilitates and supports the creation of a functioning relationship with the family. The individual has also to find, create, or be assigned to a position within the new family. Some members might accept the newcomer, while others remain aloof or even hostile for several reasons. Some families have more expectations, while others are more relaxed in their relations and attitudes. In every case, it is the individual's extent of knowledge and learning capacity that will make or break the family connection.

Intercultural and interlingual encounters, where knowledge and understanding are missing, can lead to controversial situations and even conflicts among migrants, minorities and majorities, or between whole

\footnotetext{
${ }^{4}$ We prefer to use "the individual" instead of "the foreigner", because not necessarily the person marrying into another culture comes from another country. The individual can also be a member of a minority, or a majority member who marries into a minority with other kinship concepts within the same state.
} 
societies. Politicians with other backgrounds might see relations such as nepotism in a different way than the majority, for instance. Family reunions of migrants are regulated in the Nordic countries by laws reflecting local traditions, but they often create misunderstandings for persons from other cultures and continents, and may even augment existing gender discrimination, when the underlying power and social structures remain unrecognised. On the other hand, for people in Serbia and Bulgaria, the new Swedish family constellations, names like "plastic family", and the distanced way people relate (as they are perceived from the outside) to each other within a family in the Nordic countries can be utterly baffling.

\section{Multilingual and multicultural approach}

The choice of a multilingual and multicultural comparative approach for this pilot study between Swedish kinship terminology used in Sweden and Finland, and two Balkan Slavic languages, Serbian and Bulgarian, can be a possible way to break down the illusory barriers of nations, and focus instead on the larger picture of shared cultural and linguistic spheres, the complex factors that influence them, and their convergence or divergence. In addition, we emphasise the importance of multilingual and multicultural learning as opposite to the more common term foreign language learning, and discuss some of the challenges a student encounters when trying to discover and map out a new language and culture.

The multilingual ${ }^{5}$ and multicultural ${ }^{6}$ learning aspects of kinship structures and terminologies is an important dimension that should be covered on a broader scale. Students who are involved in multilingual and multicultural education, for instance when studying another language or culture at university, are popular study objects for educational experiments, but most research on multilingual and multicultural education still deals

\footnotetext{
${ }^{5}$ For a general discussion and global examples about multilingualism, see for example Marilyn Martin-Jones, Adrian Blackledge and Angela Creese (eds.), The Routledge Handbook of Multilingualism (Oxon/New York: Routledge, 2012).

${ }^{6}$ A general overview about multicultural learning and education is provided for instance in James A. Banks (ed.), The Routledge International Companion to Multicultural Education (New York: Routledge, 2009).
} 
with schoolchildren, foreign students and migrants. ${ }^{7}$ There is even no clear and common definition yet, only several often conflicting theories and hypotheses, for the concept of multilingual and multicultural education. The baseline is, however, that it includes at least two languages and two cultures.

Here we use the concepts of multilingual and multicultural in their literal sense - multiple languages and cultures - to emphasise the fact that all students of another language and culture deepen their knowledge of their home and school language(s) and culture(s), too, in order to have a reference and a mirror, in which to reflect the new world(s) they are studying. Most Europeans, for example, have learned at least one other language at school, if not already at home. ${ }^{8}$ This means that when they are learning a new language, they are actually studying several languages and cultures at the same time, using and expanding their previous knowledges as well. Often also extra languages and cultures come into play in the language learning process, for instance when learners are looking for information on the internet, reading literature or trying to understand new concepts.

Further, the fact that the majority of humanity is multilingual and multicultural must always be taken into account. Opposite to public opinion and the belief of many scholars, monolingualism and a monolithic culture is not the global norm, but a nationalist myth dating back to the nineteenth century. Using outdated terms like "foreign language education" or "learning foreign cultures" is not productive; in addition to the fact that the term "foreign" creates both distancing and exclusion as well as emotional blocks, many learners do not perceive the new languages or cultures as "foreign" anymore, as learners would do still some thirty years ago. Today most people in the world are acquainted with several languages, cultures and societies through among others TV, radio, newspapers and the internet,

\footnotetext{
${ }^{7}$ For an overview of multilingual education, see for instance Ofelia García, Angel M. Y. Lin and Stephen May (eds.), Bilingual and Multilingual Education (Third edition; Cham: Springer, 2017); and Wayne E. Wright, Sovicheth Boun and Ofelia García (eds.), The Handbook of Bilingual and Multilingual Education (Chichester: Wiley Blackwell, 2015). Wright et al. discuss different definitions for multilingual education in the Introduction on p. 1-2.

${ }^{8}$ Eurostat (European Union) 2019: Foreign language skills statistics https://ec.europa.eu/eurostat/statisticsexplained/index.php?title=Foreign_language skills statistics
} 
and also through travels and literature, migration, and narratives of relatives or friends who have migrated or travelled.

An increasing number of the global population is mobile today, and intercultural connections and mixed marriages are becoming more frequent. The need for information and understanding the other end of Europe is getting acute, not only for students of languages and cultures, but for all Europeans, and the same is true also outside Europe. Migration has for several decades been an important aspect in the contacts between Sweden and Serbia (and previously Yugoslavia), but in the modern European context other kinds of connections are created on several levels. Not only citizen diplomacy, but all kinds of relations and contacts are growing with a fast pace since the 1990s. ${ }^{9}$

This article is neither a purely anthropological nor a linguistic study, but cross-disciplinary comparative research moving on the south-north axis of Europe. Urbanisation processes have changed the societies profoundly during the past century, but presenting the change from a rural to an urban system, or going back to earlier periods in language and culture would remove the focus from multilingual and multicultural issues and the analysis of learning processes. Historical research could shed some light on the development up to the present, but it figures here chiefly in the background.

This study can therefore be categorised as a modern intra-European analysis on the kinship complexity and terminology, viewed through the magnifying glass of the learning process. The article is an introduction to the topic and by no means exhaustive. We use different viewpoints, looking at each other from both sides of the mirror. This is made possible due to the fact that the authors of this article have a long history of Balkan-Nordic and Nordic-Balkan connections; both have done multicultural and multilingual journeys many times, and participate in multiple societies with multiple identities; the authors also have extensive personal and academic experience

\footnotetext{
${ }^{9}$ See Dorijan Hajdu and Sabira Ståhlberg. “A Fly in Amber? Nordic-Balkan Citizen Diplomacy and Cultural Connections Then and Now." Journal of Baltic and Nordic Studies, Vol. 12, issue 2 (2020): 7-48.
} 
in multilingual and multicultural issues, as well as in crossing, stretching and bending cultural and linguistic borders. ${ }^{10}$

\section{Mapping out kinship terminology}

The purpose of this study is to map out some of the current terminology and concepts of family relations in Swedish, Serbian and Bulgarian, and to discuss challenges and ways to acquire knowledge about them. Through a small-scale survey we explored the importance and understanding of a group of Serbian students of foreign languages and cultures, all in their twenties, about their social connections and perceptions of kin. A further dimension in this article is the analysis of the changes or shifts in the kinship understanding when studying another culture and language.

If we follow the assumption that a language is the mirror of its culture, and that language influences culture and society, on a deeper level the linguistic terms designating family relations can reveal a number of interesting phenomena and questions, among others:

- Which relations occupy the centre of importance in the society?

-What are the concepts, definitions and understandings of what is a core family versus an extended family?

-Which family relations are considered "worth" having a term for, and thus valuable to keep up?

- What are the family relations after a crisis, for instance a divorce?

\footnotetext{
10 See among others Sabira Stahlberg 2020a, Multicoloured book (Helsingfors/Helsinki: Bokpil, 2020); 2020b, Multicoloured language (Helsingfors/Helsinki: Bokpil, 2020); Dorijan Hajdu, Pragmatična ekvivalencija izraza sa konotativnim značenjem u švedskom i srpskom jeziku [Pragmatical equivalence between expressions with connotative meaning in the Swedish and Serbian languages] (Universitet Beograd: Filološki fakultet [University of Belgrade: Philological Faculty], 2018); Dorijan Hajdu and Jelena Drljević, “Uticaj vladajućih kognitivnih kulturnih modela i vrednosti na uvredljive izraze vezane za figuru majke $u$ švedskom i italijanskom jeziku" [Influence of ruling cognitive cultural models and values on expletives connected to the figure of mother in Swedish and Italian], Komunikacija i kultura online [Communication and Culture Online], god. 9, br. 9 (2018): 59-75.
} 
- How are family relations transferred to friendship and business contacts?

In this study we discuss linguistic and cultural questions concerning kinship and its terminology, by exploring these relations from perspectives including cognitive anthropology and sociolinguistics, but mainly through the prism of multicultural and multilingual learning and accumulation of competence and understanding. We ask what kind of conclusions can be reached by analysing the language used to depict Swedish-language family trees in comparison with Serbian and Bulgarian, and how they connect to culture and society.

The Nordic countries are usually seen as individualistic with focus on personal independence and freedom. The people from the North trust each other and the state structures much more than people do in the South. The Balkans, on the other hand, is seen as a family-dependent, gender-biased region, where people trust family and friends more than the state or any official institution. Being invited home means that the guest is considered a close friend. In the Nordic countries, inviting new acquaintances or even strangers to a home is completely acceptable. ${ }^{11}$

But is it really like this? This article can be seen as a Nordic-Balkan comparative study, which does not have as its goal to universalise or to create another theory or model, but to highlight through a few linguistic examples the cultural patterns we grow up with and continue implementing as adults; and how the learning of another pattern poses a challenge to our basic concepts, how we can deal with it and simultaneously be aware of both our own and other peoples' concepts. Concretely, this study contains a discussion about the following three questions:

\footnotetext{
${ }^{11}$ See Hajdu and Drljević, "Uticaj vladajućih kognitivnih kulturnih modela”, for more on cognitive cultural patterns in Swedish and Serbian societies, individualism and family relations; Henrik Berggren and Lars Trägårdh, "Pippi Longstocking: The Autonomous Child and the Moral Logic of Swedish Welfare State", in Swedish Modernism: Architecture, Consumption and the Welfare State, eds. H. Mattsson and S-O. Wallenstein (London: Black Dog Publishing, 2010), 50-65; Henrik Berggren and Lars Trägårdh, "Social Trust and Radical Individualism. The Paradox at the Heart of Nordic Capitalism", in The Nordic Way: Equality, Individuality and Social Trust, eds. A. Rembe and K. Persson. (Stockholm: Swedish Institute, 2012), 13-29.
} 
1. When we start learning about other kinship systems, the first challenge is terminology. Who is a relative? How does language reflect family relationships? Which relations occupy the centre of attention in society, and are considered important enough to have a word for?

2. The second question is about change. We live in an incessantly changing and flexible world. Marriage does not necessarily form the basis for kinship any longer; there are new, diverse forms of family nowadays. How does language reflect these new forms and transformations? (Globally, Swedish is probably the language with the largest collection of new family words.)

3. Our third topic is the extension of kinship outside the family with common ancestors, for instance to godmothers and godfathers or marriage witnesses, but also to business partners and friends. This way of extending the family relations is especially important in Serbia and Bulgaria.

\section{Learning kinship patterns}

The first task, however, is to examine the way humans learn kinship patterns and terminology. We use the term "pattern" instead of model, because a pattern is more flexible and allows for changes, while "model" implies that there is a fixed social model applied to the whole society, which is neither true nor realistic. Western scholars prefer traditionally to speak of cultural models, ${ }^{12}$ but that is to limit and generalise too far. Most families and kins have their own characteristics which might or might not be shared with society. Although there often are shared attitudes and values with society, to speak of social models would be to ignore the dynamics and changes occurring both inside and outside families and kinship structures, and within societies, too. We are well aware of general opinions reflecting the myth that there are fixed national models, so our term choice signalises a

\footnotetext{
${ }^{12}$ Cognitive cultural models in general are discussed by for example Roy D'Andrade, “A folk model of the mind", in Cultural models in language and thought, ed. N. Quinn (Cambridge: Cambridge University Press, 1987), 112-150; and Penelope Brown, "Cognitive Anthropology", in Language, Culture, and Society, eds. C. Jourdan and Kevin Tuite (Cambridge: Cambridge University Press, 2006), 96-115.
} 
deviation from the national mythologisation, and also a desire to look into ongoing social processes instead of static concepts or theoretical constructions.

"Whose (child) are you?" This is a question children encounter very often in the Balkans, but also in the Nordic countries adults ask whose kids we are from the moment we learn to speak. The question develops into "Where do you come from?" for adults, who happen to be present somewhere, where they are seen as foreigners. The place does not necessarily have to be another country, but can even be the country, town or even street where they grew up. Both questions are about identity and the characteristics identifying a person, and they show the intent of the interlocutors to define where the stranger belongs.

The concept of "belonging" is not only the family or kin, but also the town and country where an individual "comes from", and fundamentally, the nation. A category is required by the interlocutors, so that the individual can be treated in the way the interlocutors believe this person should be dealt with. Their behaviour is based on their personal experiences, ideas about the world, and of course their misconceptions. ${ }^{13}$ This automated categorisation can go very wrong and be both exasperating and infuriating to all involved. Every person whose fluent language skills, appearance or other elements, which do not fit into national stereotypes or are combined in the "wrong" way, has experience of this. Multilingual and multicultural persons often fall outside these generalised and illusory categorisations. Still, the majority of the world's population appears to be happily holding on to national stereotypes, although nobody is a "typical" Swede or Serb.

The clichés are seen as something natural, but this categorisation is in fact learned in childhood from adults. The family has been the foundation for human relationships since prehistory and we see it as something extremely normal. We learn as children that we belong to a specific family unit, and we learn the basic concepts and behavioural patterns at home. As

\footnotetext{
${ }^{13}$ Questions like "Where do you come from" or inquiring about someone's background, language etc. are today considered to be microaggression, as they convey the idea of exclusion, alienation and degradation, among others. For more information on microaggression, see for example Derald Wing Sue and Lisa Spanierman (eds.), Microaggressions in everyday life (Second Edition, Hoboken: Wiley, 2020).
} 
adults, we continue to reinforce them in our own lives, both in the way we speak, act and make decisions. Our identities depend very much on the family background. Slowly, while growing up, we expand our kinship patterns and apply them to social and ethnic groups, networks and nations. Kinship structures and terminology are extremely resilient and might continue for centuries, and also the extensions or refusal of kinship to other groups and nations can be persistent. The patterns of course differ in every society and even within societies between different groups.

Parents transfer their patterns to the next generation - this is an integrated part of the upbringing. The cognitive cultural patterns we learn as children also shape the way we perceive the world. That is why it is so hard to change cultural patterns. Many things we simply do not see, because we perceive them as normal. Most of us are not aware of and never question our family patterns and behaviour or that of others within the same culture. We have learned that there is a "model" for the things we do, think and believe in life, and not many reasons to deviate from it. As far as we can see (and most people do not look very far), millions of other people with the same national self-definition around us act, think and believe in the same way, so we are confirmed in the belief that there must be a common model. Only if someone disrupts the socially accepted code we start paying attention. We expect everybody to follow the dominant cultural and behavioural patterns in our society, and in fact most of us adhere to them for most of our lives.

If we behave in the way we are expected to, we get a reward. Rewarding begins as praise when children do the correct thing or behave as they are expected. The adults, who are the authorities for a child, show and express in words and behaviour their acceptance or disapproval. As adults we continue to try to fit into society, at least into our immediate surroundings. We are not foreign or strange when we do the "right" thing. Roy D'Andrade summarises the socialisation process in the following way:

...through the process of socialization individuals come to find achieving culturally prescribed goals and following cultural directives to be motivationally satisfying, and to find not achieving culturally prescribed goals and not following cultural directives to be anxiety producing. 
When we study another culture, we often receive compliments for our linguistic and cultural competence, especially if we speak the language fluently. We get the classical question less often: "Where do you come from?" This means that we have been accepted, and we have at least some right to "belong" to this specific group. The most important thing for humans as social beings is to feel that they are accepted. If they are or remain outsiders, their survival is at stake. This primary response prompts adults to repeat the same behavioural patterns they learned as children. They want to fit in and be part of a group or society.

When we encounter other kinship systems, we need to move out of our existing, comfortable world of concepts. Yet learning new family terminologies, values, names and customs is not very different from any other cultural, linguistic or social patterns we learn. They require some time and effort, but the learning process is highly rewarding both socially and emotionally, when we find that we can function in another system as well. While learning, we start seeing our own culture and background, and also other people from a different point of view.

\section{Balkan and Nordic kinship terms}

In the following we discuss through the example of family words a common first encounter with another culture. Language teaching often offers at least some family terminology in textbooks, but also a meeting with the family or relatives of friends, a future spouse or a colleague can trigger a need for new kinship concepts and terminology. Family meetings are usually a first cause for confusion for an individual from another culture.

Serbian or Bulgarian family terminology seems to be very complex and complicated for a Swedish-speaker, who has grown up in a core family and possesses a simple kinship system. There is a vast variation of terms and they appear to cover all imaginable relations a person can have. In Table 1 is shown only a part of a long list of different kinship terms in Serbian and Bulgarian. Many of the terms overlap, pointing at a shared heritage and also at an existing regional cultural pattern, but there are also some differences. 
Pronunciation in Latin script (italics) is added to the Bulgarian terms in Cyrillic script.

Table 1. Serbian and Bulgarian kinship terms

\begin{tabular}{|c|c|c|}
\hline Serbian & Bulgarian & English translation \\
\hline $\begin{array}{l}\text { Majka, } \\
\text { mama }\end{array}$ & Майка, мама Mayka, mama & Mother, Mum \\
\hline Otac, tata & Баща, тате Bashta, tate & Father, Dad \\
\hline Dete & Дете Dete & Child \\
\hline Ćerka & $\begin{array}{l}\text { Дьщеря, щерка Dăshterya, } \\
\text { shterka }\end{array}$ & Daughter \\
\hline Sin & Син $\operatorname{Sin}$ & Son \\
\hline \multirow[t]{2}{*}{ Brat } & Брат Brat & Brother \\
\hline & Батко Batko & Elder brother \\
\hline \multirow[t]{2}{*}{ Sestra } & Сестра Sestra & Sister \\
\hline & Кака Kaka & Elder sister \\
\hline Deda & Дядо Dyado & Grandfather \\
\hline Baba & Баба Ваbа & Grandmother \\
\hline Unuče & Внук Vnuk & Grandchild \\
\hline Unuk & Внук Vnuk & Grandchild (boy) \\
\hline Unuka & Внучка Vnuchka & Grandchild (girl) \\
\hline Tetka & Тетка Tetka & Mother's sister \\
\hline Tetka & Леля Lelya & Father's sister \\
\hline Teča & Свако, калеко Svako, kaleko & $\begin{array}{l}\text { Parent's sister's } \\
\text { husband }\end{array}$ \\
\hline Ujak & Вуйчо Vuycho & Mother's brother \\
\hline Ujna & Вуйна Vyuna & $\begin{array}{l}\text { Mother's brother's } \\
\text { wife }\end{array}$ \\
\hline Stric & Чичо Chicho & Father's brother \\
\hline Strina & Стринка Strinka & Father's brother's wife \\
\hline Rođak & Братовчед Bratovched & Cousin \\
\hline Dalji rođak & Роднина Rodnina & Relative \\
\hline
\end{tabular}


In both languages there are additional dialectal, regional and diminutive variations and forms, which have not been added here; it would be an interesting topic for a separate study. Family differences also exist: forms derived from the Bulgarian word for 'mother' майка mayka, such as маменка mamenka, is used for 'grandmother' in several families. Traditionally, when a couple marries in Bulgaria, the young couple starts calling each other's parents Mother and Father. There are also words for the brother of the wife (шурей shurey); his wife is шуренайка shurenayka, while two sisters' husbands are called баджанак badzhanak. The wife's sister is балдъза baldăza, and зъдва zălva is the sister of the husband; the sister's husband is зълвеник zălvenik. The list goes on with different words for the in-laws, father of the wife (тъст tăst), mother of the wife (тъща tăshta), father of the husband (свекър svekăr), mother of the husband (свекърва svekărva), son-in-law (зет zet), daughter-in-law (снаха snaha), etc.

At the other end of the family terminology spectrum in Europe, Swedish family terminology is pretty straightforward (Table 2) - that is, for a Swedish-speaker. For a language learner coming from Serbian or Bulgarian, Swedish kinship constellations can be a mystery. The terms for grandparents are derived from core family members and the parents' brothers and sisters follow the same pattern. The terminology looks very simple, but it can be confusing, as it might be difficult to remember if the prefix or the suffix tells to which side of the family a person belongs. In Swedish the prefix defines the side. Also the in-laws just receive an additional prefix, svär- (svärmor, svärfar, svärdotter, svärson; svåger is the husband of a sister and svägerska is the wife of a brother).

\section{Table 2. Swedish kinship terms}

\begin{tabular}{|l|l|}
\hline Swedish & English translation \\
\hline Mor, mamma & Mother, Mum \\
\hline Far, pappa & Father, Dad \\
\hline Barn & Child \\
\hline Dotter & Daughter \\
\hline Son & Son \\
\hline
\end{tabular}




\begin{tabular}{|l|l|}
\hline Bror & Brother \\
\hline Syster & Sister \\
\hline Morfar & Mother's father \\
\hline Mormor & Mother's mother \\
\hline Farfar & Father's father \\
\hline Farmor & Father's mother \\
\hline Barnbarn & Grandchild \\
\hline Sonson & Son's son \\
\hline Dotterson & Daughter's son \\
\hline Sondotter & Son's daughter \\
\hline Dotterdotter & Daughter's daughter \\
\hline Moster & Mother's sister \\
\hline Morbror & Mother's brother \\
\hline Faster & Father's sister \\
\hline Farbror & Father's brother \\
\hline Kusin & Cousin \\
\hline Släkting & Relative \\
\hline
\end{tabular}

Among Swedish-speakers there are also some regional differences in the kinship terminology, both in Sweden and between Sweden and Swedishspeakers in Finland, but they are not very significant. Cousins are just named kusin in Swedish, which is a loanword from French. The cousin terminology in Sweden and Finland are somewhat different: a third-generation cousin is syssling in Sweden, and in Finland småkusin, Finnish pikkuserkku 'little cousin', while the fourth generation cousin is brylling in Sweden and syssling in Finland. In no case a connection is made to the side a cousin belongs to. Other relatives farther apart are mostly called släkting 'relative'. Yet none of these cousins and relatives would ever be called or even considered "brothers" or "sisters" in Swedish, in contrast to Serbian. Serbian children make a closer connection between their own brother or sister and cousins than their Swedish counterparts.

The difference in complexity, and attitudes defining who is important and worth having a word for among the multitude of relatives, between Serbian and Bulgarian on one hand and Swedish on the other, is visible from 
the above lists. A more complex terminology is needed and employed in a culture where kinship is of utmost importance. The close-knit family pattern is still strong in Serbian society. This is also shown by a microsurvey we carried out at the University of Belgrade with students who study foreign languages and cultures.

\section{Serbian kinship terminology survey}

Asking the question how much traditional kinship terminology is still in use, we designed a short survey to anchor our analysis of family relations. Given the simple pattern which the Swedish family terms follow, it was considered unnecessary to conduct an equivalent study with Swedish students, as we could expect the answers to be around the hundred-percent mark for familiarity with the terms. Also, several of the more complicated terms in use in Serbian do not exist in Swedish, so a comparison would not even be possible. The Serbian survey was a first test and it will hopefully in the future be followed up with other surveys adapted to different cultural conditions.

The survey was carried out in April 2021 at the University of Belgrade and the form was a questionnaire. We surveyed 19 informants in total, all of which were second- and third-year students of foreign languages and cultures at the university, aged 20 to 23 years. The Serbian-language survey was designed to give as much useful information as possible, without being too long or taking a lot of time to complete. The questionnaire contained ten questions and took about ten minutes to fill in. The informants were asked to write anonymously the answers to some questions or pick one of two offered answers in other questions. The choice answers in those questions were always in the form of "True/False" and "I agree/I disagree". Furthermore, if they chose "I disagree", the informants were asked in the following question to explain why they chose that answer, and to motivate the answer in their own words. The ten questions in the survey were as follows:

1. Write all the terms for family relations you know.

2. Which family members fall into the category of a "core family"? 
3. Which relations are represented in following terms: svastika, jetrva, pašenog, dever, svekar, zaova?

4. In Serbian culture kum (godfather) is considered a part of the family. Answer "True/False".

5. The terms maćeha (step-mother) and očuh (step-father) are neutral connotations. Answer "I agree/I disagree".

6. If you chose the answer "I disagree" in the previous question, explain why.

7. Several generations of the same family living under the same roof is beneficial for all members of the family. Answer "I agree/I disagree".

8. The term vanbračna zajednica (civil partnership) is a neutral connotation. Answer "I agree/I disagree".

9. If you chose the answer "I disagree" in the previous question, explain why.

10. I use the term brat/sestra od tetke (brother/sister of the aunt) even for relatives that are not children of my aunt (my mother's or father's sister). Answer "I agree/I disagree".

The in-depth analysis of the answers from this survey are easier to read and understand, when we separate them into four subcategories, based on the characteristics which the questions were designed to reveal. In the end we will offer a summary of the results.

1. Basic knowledge of the terms: The fact that the Serbian language has a wide variety of terms for all kinds of different family relations is well known. But the fact that the terms exist does not prove that they are used or even known by the speakers of that language. Our main idea with these questions was to see what these terms convey to young people today. Are the words only used by elderly people, still remembering life in large and strongly connected families where a term for every possible relation was needed? Based on the relation between language and culture, this group of questions should show if the terms are abandoned, never learned or forgotten by young people today, or if they still are in active use in the society as a whole, including the younger generations. 
The answers clearly show that the wide range of kinship terms is actively present in the informants' vocabulary, with $95 \%$ of the answers listing most of the available names for family relations, including the more "obscure" ones (that is, not only the closest or core family). Even if some of the informants could not define exactly the relation the term is tied to, it is safe to say that all of them were absolutely aware of all the terms.

The third question further confirms this, with four of six words getting the correct definition. The correct answers range from $53 \%$ for zaova (husband's sister), 63\% for svastika (wife's sister), 79\% for dever (husband's brother), to $89 \%$ for svekar (husband's father). Of the two terms which received under $50 \%$ of correct definitions, it is worth mentioning that jetroa (husband's brother's wife) is on the border with $47 \%$, leaving in truth only one term - pašenog (wife's sister's husband) - which could be classified as "difficult" with $21 \%$ of correct definitions or no definition at all. It is also important to note that in the incorrect definitions, the answers given were not that far off the mark.

2. Categories are clear, even when there is uncertainty about the term itself. There was for example an uncertainty regarding zaova (with $47 \%$ of incorrect answers - all of which were actually offered and no blank spaces were left by the informants) as to whether it is brother's wife or husband's sister. None of the incorrect answers mistook the sex of a relation the term is "derived" from: it was either a husband (correct) or a brother (incorrect), but in any case, a male relative.

Furthermore, there was never a mistake regarding the generation of a female relative to the male relative the term is derived from: a wife or a sister were never mistaken for a mother or a daughter. None of the informants wrote for instance that zaova is the husband's mother or brother's daughter. We would argue that these two questions show that the family relation terms in Serbian culture are still actively used among the younger generation, who is familiar with most of them. It is probably safe to suppose that the results would be even higher with older generations and rural informants.

3. Family members, brothers and sisters extend outside the core family. The definition of $u \check{a} a$ porodica (core family, nuclear family), which can be found 
on most websites and in online dictionaries, is a family of two parents and their children, corresponding with other languages such as Swedish with its definition of kärnfamilj. Our hypothesis was that in the Serbian culture this term would at least to some extent cover more than just the parents and their children.

The second question was therefore aimed at the definition of a core family and which members are considered to belong to the nucleus. Almost half of the informants (47\%) listed at least grandparents, with half of the students writing that also the parents' sisters and brothers and their children also belong to the core family, that means basically the grandparents' children and all of their offspring. Again, this is the view of the young generation, clearly showing that the cultural influence has an equally strong input as the dictionary definition.

The same wave continued into the seventh question, where $26 \%$ of the informants agreed with the statement that "more generations of the same family living under the same roof is beneficial for all its members". Bearing in mind that these are young, university-educated, globalised and multilingual adults, the cultural influence is again clearly visible; we would assume that the percentages based on the entire society would be much higher.

4. A large family is seen as the basis, but society is changing. How far the notion of a 'brother' or a 'sister' goes is a crucial question: we can use it to draw a line and connect the language back to the cultural patterns and further to the mind of a language user. While in most other Indo-European languages the term 'brother' and 'sister' is used solely for the relatives who share the same parents, in Serbian culture and consequently in the language this term is widely used for other relatives as well. The children (cousins) of the parents' brothers and sisters (aunts and uncles) are by definition considered brothers and sisters.

This notion goes even farther than that, which the tenth question in our survey was supposed to show. A complete $95 \%$ of the informants answered affirmatively to the statement "I use the term brother and sister (of the aunt) even for relatives that are not children of my aunt (my mother's or father's sister)". It means that the notion of a sister or a brother in Serbian 
culture spans much wider than even the broadest definition of a core family, "instructing" the individual to connect even the more distant relatives with the same term used with the closest ones. We can therefore conclude that the extended family relations were and still are of the greatest importance in this culture.

\section{Social changes and globalisation}

When learning a new kinship terminology and culture, it is very important to know one's own system and terminology. Knowing the concepts and being able to name also distant relatives supports the learning of new terms, which can be matched against the already existing ones. This gives an advantage to a Serbian or Bulgarian learner of Swedish over a Swedish learner, who is acquiring Serbian or Bulgarian family structures: using more complex terms, the Serbian or Bulgarian learner can more easily catch the much simpler Swedish system, despite some confusion at the beginning and especially with the new family terms. In both cases, the learners must map out the relations and understand the connections simultaneously together with the learning of the terminology.

In Swedish, kinship terminology has never been very rich even in historical times. Earlier, some older terms such as onkel 'uncle' existed, but they have disappeared. Words no longer required in a society tend to disappear from its language. On the other hand, new terminology is created when the need arises. Swedish offers today a wide range of vocabulary solutions for alternative family forms. Flexibility is a second remarkable difference between the Swedish and Serbian languages and cultures, after the first difference which is the quantity of family terms. Swedish-speakers are for historical and social reasons more inclined than Serbians or Bulgarians to create new, fanciful words for family. In Sweden, new family forms have emerged in the past few decades, and consequently a vast field of different terms for the family forms has appeared. 
Table 3. New Swedish family terms ${ }^{14}$

\begin{tabular}{|l|l|}
\hline Swedish & English translation \\
\hline Sambo & Partner, living together \\
\hline Särbo & Partner, living separately \\
\hline Mambo & $\begin{array}{l}\text { Person living with mother / } \\
\text { parents }\end{array}$ \\
\hline Exbo & Partner, previous co-habitant \\
\hline Partner & Partner \\
\hline Family forms (add -family, -mother, & -father, -brother, -sister, etc) \\
\hline Bland- & Mixed \\
\hline Flex- & Flexible \\
\hline Bonus- & Bonus \\
\hline Styv- & Step- \\
\hline Extra- & Extra \\
\hline Umgänges- & Socialising \\
\hline Frånvarande & Absent \\
\hline Deltids- & Part-time \\
\hline Söndags- & Sunday \\
\hline Helg- & Holiday \\
\hline Varannanveckas- & Every second week \\
\hline Distans- & Distance \\
\hline Ombildad & Transformed \\
\hline Lapptäcks- & Quilt \\
\hline Plast- & Plastic \\
\hline
\end{tabular}

None of these Swedish terms exist as yet in Serbian or Bulgarian. The only expressions used in Serbian for relations between people who are not officially married are vanbračna zajednica 'extramarital unity' and nevenčani suprug, nevenčana supruga, 'unmarried husband' and 'unmarried wife'. A

\footnotetext{
14 These new Swedish family terms have been compiled for the article through searches on the internet in dictionaries, legislation, newspapers and blogs. Only the most popular have been included here. A Finland-Swedish viewpoint by Monica Äikäs (Språkbruk, 2006) can be read here: https://www.sprakbruk.fi/-/plastfamiljer-umgangesforaldrar-och-mambor
} 
term such as bonus porodica 'bonus family' could be imagined, but there have been no attempts to replace the existing and to a certain degree negative terms of non-married couples with any neutral ones.

In Bulgarian the options are a little more elaborated: the unmarried couple can be referred to as "partners" or legally as a couple "living together as family" (на семейни начила, na semeyni nachila). However, usually the unmarried couple refer to each other as "husband" and "wife", "friend" (male or female form) or "partner", and often also the in-laws are called with the traditional terminology. Although in Bulgaria marriage is still seen by many as the norm, the numbers appear to be diminishing especially among the younger generations. The non-married couples comprise more than half of all couples living together today, and around $60 \%$ of the children were born out of wedlock in $2020 .{ }^{15}$

This indicates to the learner that when learning about another culture, it is important to follow the processes and the development of the society. The learner also needs to pay attention to and understand how different groups and the families the learner encounters in society perceive kinship relations. Individual or family attitudes might differ widely from mass media reports or opinions, statistics or views expressed in chat forums. Respect for traditions might for instance be talked about, but not practised, or practised only to some degree. To detect the variations require often deeper language skills and more social and cultural experiences, but the variations are visible under the surface of simplified and standardised views, if the learner wants to look at them.

\section{New family terms: challenges}

While the existing terms for traditional family members are as broad as they can be in Serbian, there is a notable contrast when it comes to the names for other types of families, such as new family the parents for instance form after a divorce, the civil partnership (two people living together without being officially married) and others. The questions 5-6 and 8-9 in

\footnotetext{
${ }^{15}$ National Statistical Institute, Bulgaria, marital and extramarital births in 2020: https://www.nsi.bg/en/content/2963/marital-and-extra-marital-live-births-districtsmunicipalities-and-place-residence
} 
our survey with students in Belgrade were designed to give an insight into how these types of families are viewed in the Serbian culture by the young generation, given the lack of alternative terms in Serbian language.

The terms we find in this context are maćeha (stepmother) and očuh (stepfather). These terms, as is the case in Swedish with styvmor and styvfar, are coloured by traditions and folklore, folk tales, sayings and expressions, all with different degrees of negative connotations. ${ }^{16}$ The figure of the evil stepmother abounds especially in folk tales and is enforced by internationally known fairy tales (Cinderella, Snow White, Hansel and Gretel and many others). In the survey we wanted to check if the informants would define these terms in Serbian as neutral, given the fact that no other terms are offered as a possible replacement for the existing ones.

As many as $74 \%$ of the informants defined them as having a negative association, citing a traditional saying - "Life is a mother to some, and a stepmother to others" (meaning life is good to some and bad or hard for others) - as one of the main reasons. Other explanations offered were that in Serbian culture the idea of family is highly valued, and that a "new" family after a divorce (in Swedish it would be called a "bonus family") is still regarded as something unconventional and even wrong. This corresponds with the idea that the patterns present in a culture are mirrored in its language: the lack of other terms - neutral, if not positive - would lead us to believe that there is no need for such terms in a culture, which still widely views the "other" family as something out of the ordinary.

The same thing can be said about the term vanbračna zajednica (civil partnership). A simple etymology analysis shows that such partnership, instituted also by law, is derived from the word brak (marriage) and it means literally a "union outside marriage", showing that marriage is the core institution and other forms of partnerships are judged and defined by it. This term in itself has no connection to folk tales, and it is very neutral and official. Even so, almost half of our informants thought that this term also has negative connotations (42\%), explaining the same "unusualness" of it as

\footnotetext{
${ }^{16}$ A search for "styvmor" in Svenska Akademiens Ordböcker (Swedish Academy Dictionaries https://svenska.se/ ) yields several Swedish quotations and sayings, most of them showing the lack of love and cruel behaviour of stepmothers.
} 
opposed to regular marriage. Although these relationships (both the "new" families and the civil partnerships) have become much more common in the last decades, there are no other terms in Serbian that would function as a neutral or positive term for this type of relationship or the "new" family members.

On the other hand, there is a large number of terms in Swedish to describe different forms of non-marital relations, depending on whether the partners are living together or not. The main term that would correspond to Serbian term vanbračna zajednica would be the very usual Swedish word sambo, short for sammanboende 'living together', a word which describes the relationship in the simplest way as two people sharing an accommodation and relationship, without comparing it to or deriving it from marriage. Other terms present in Swedish and missing in Serbian are särbo, meaning a relationship where people are together but do not share an accommodation, and also delsbo, where people in a relationship occasionally live together. This reflects the social need to define different kinds of relationships, which exist in a society, without tying them in any way to a traditional marriage.

Today globalisation is a strong driving force for changing family relationships. In Serbia and Bulgaria kinship structures are moving towards core family due to social, economic and other factors such as urbanisation and migration. Migrants with other ideas of kinship are slowly changing also the Nordic concepts of family relations. How much these current trends will change the societies remains to be seen in the future. Yet at least concerning trust the Nordic countries and the Balkans have not changed much in the past decades.

\section{Extending the family}

Do you trust a person at first sight? Who do you call, when you need something? Do you dial a relative, a friend or an institution? What are you ready to do for other people? These are not only questions about faith in others, but also how individuals perceive their relatives, and further, how they define who is a relative. When learning about another culture and language, we also learn about trust and how to deal with different kinds of situations, which involve believing or not trusting other people. 
Research shows that people in the Nordic countries are more likely to rely on strangers compared with Balkan countries. They also expect the state and official institutions to take responsibility to a much higher degree than in the Balkans; the power distance is shorter. People from Serbia and Bulgaria trust family and their extended family, but they have little trust in the state. Whatever happens, the family is there to support, provide safety and take care of any situations. ${ }^{17}$

The Serbian and Bulgarian kinship patterns are, as we have seen, not limited just to the core family. Support networks are built up also with an extended family. A godfather or godmother becomes a kind of relative both in the Nordic cultural sphere and the Balkans, but in Serbia and Bulgaria the relationship is closer, and marriage witnesses become relatives, too. The "title" of kum (godfather and best man) is well-known and widely documented in Serbian culture and literature. In Bulgaria this person is important, but has today less social significance than before and there are fewer consequences for the person after the wedding. In Serbia being kum is considered an institution in the same way that a marriage is. Becoming kum is an honour, the evidence of strong friendship ties and proof of the overall good qualities a person possesses. It can easily be classified as a title of honour given to someone by their (best) friend. While the best man present at a wedding is merely a vittne (witness) in Sweden, it is a bond of huge proportions in Serbia.

Even with the broad spectrum of terms for family relations present in Serbian, the family becomes even bigger when a person marries and asks a friend to be godfather or -mother. He/she is after that for all intents and purposes part of the family. Many people use the term kum to address the witness after the wedding instead of the kum's name, with the word functioning basically as a given name. It is also usual that the children view the parents' godfather as their own godfather and call them kum. A deeper discussion around the person of kum goes beyond this article, but we should note that $95 \%$ of the informants in our survey chose "true" as the answer to

\footnotetext{
${ }^{17}$ See Berggren \& Trägårdh, "Social Trust and Radical Individualism”. Compare also the scores of Sweden, Finland, Serbia and Bulgaria with Geert Hofstede's six criteria at Hofstede Insights: https://www.hofstede-insights.com/product/compare-countries/
} 
the statement given in the fourth question of the survey: "In Serbian culture, kum is considered to be a part of the family".

Other categories of people to whom kinship might be extended are friends, fellow students, business partners and colleagues, and others with whom an individual builds up trust over a longer period. Often the relationship starts in childhood, youth or during student years. The kinship is not necessarily acknowledged openly and family terms might not be used. Still, the behavioural patterns with the extended family, who are no blood relations, are very much the same as with family and kin.

The extended kinship behaviour applies also to others who speak the same language and/or share the same or a similar culture, especially in the global diaspora of migrants. For Serbians and Bulgarians abroad, a friend of a friend becomes a relative. The kinship behaviour pattern can be spread even further: anybody else from the Balkans can become part of the extended family. Mutual understanding is present and the social codes are clear to all. When talking about other Serbs, the pronoun "ours" or "our own" is commonly used instead of the adjective "Serbian" or the noun "Serbs". For instance: "Are those people over there foreigners? No, they are ours." Jesu li ono stranci? Ne, naši su.

\section{Conclusions}

The biggest differences between Serbian and Bulgarian on one hand, and Swedish language, society and culture on the other, can be summarised thus: the discrepancy in the number of terms for certain family relations, the degree of adaptation and the differences in inclusion. This goes both ways, namely, the number of terms depicting traditional family relations is incomparably larger in Serbian, while the terms for "alternative" types of families are more present in Swedish. If we view a language as a mirror of its culture, these differences would lead to findings showing that there is a difference in how the family is perceived and thought about in these cultures, or more concretely: there is a disparity in cognitive cultural patterns regarding family in these Nordic and Balkan cultures.

The first big difference between Swedish (Sweden and Finland) on one side and Serbian and Bulgarian on the other, and indeed between the 
two larger cultural spheres is the number of terms covering all imaginable family relations in Serbian and Bulgarian. Apart from the core family names, none of those terms are present in the Swedish language. The fact that such a big percentage of the young informants in our survey at the University of Belgrade is familiar with so many of the traditional kinship terms shows that the traditional cultural pattern is still prevalent in the Serbian society. The fact that some older kinship terms in Swedish are no longer in use can be viewed as a piece of evidence that words, which are no longer useful in a culture, disappear from its language.

This leads to the second difference: the willingness to adapt a language to changing social relations. In Sweden, the terminology for professions and family has been in a process of change for several decades. New forms of partnerships, very common in Sweden, are becoming more present also in the Balkans. Bulgarian and especially Serbian are still far from any neutral terms, which could replace the ones carrying a negative connotation, because of folklore, proverbs and other everyday expressions based on traditional terminology, and also because of social attitudes towards new forms of families. The overall view of non-standard families in especially Serbian society is still something out of the ordinary and as such undesirable. The fact that the wedding witness, $k u m$, is considered a part of the family further underlines the importance of the institution of marriage. In comparison, the social changes in Bulgaria have brought on a slight change also in the terminology, but still the marriage-based terms are used in everyday language.

The third difference is the inclusion of persons who are not blood relatives into the family. In Serbia and Bulgaria, friendships are seen as close as family relations, although not necessarily family terminology is used. In Sweden and among Swedish-speakers in Finland there is a clearer distinction between family and friends and a greater social distance. Moving into a Serbian or Bulgarian family can be a challenge for an outsider, until the right term for the newcomer has been found and through the term the newcomer's position is defined. When the individual has joined the family and received a suitable designation, there may be expectations about behaviour and attitudes which are "appropriate" to the position in the 
family. Expectations can be found in the Nordic countries, too, but in our experience to a lesser degree, because there is often a greater social distance between the several core families which make up the kin.

This pilot study is limited in scope and size, but there are several questions which require further research. The globalisation of the cultureand language-specific environment and social attitudes, through media and other channels such as the internet, movies and social media influencers, who increasingly define how especially young people see their families and relatives, should be included in any future analyses on family patterns and terminology. Migrants and other persons living in multilingual and multicultural families and situations should be part of this discussion, too, but they remained outside the scope of this article due to length limitations.

The linguistic aspect of kinship has received much less attention than family structures. Definitions, terms and the naming of different categories of relatives are frequently mentioned in academic studies, especially in anthropology. Yet the question what they actually represent and reflect outside the concrete definition of a specific relative or the kinship structures has been little explored. Why certain terms exist in some but not in other societies, and how they mirror the cultural and social contexts is an important topic, which remains open to research. A comparative perspective could provide much interesting information on cultural connotations, among others.

Studying another language and culture is always a great challenge, and kinship systems are an important part of the learning process. We have to not only change ourselves, our behaviour and concepts while learning, but also our way of thinking and understanding human relationships. This is a fundamental aspect of the multilingual and multicultural learning. If we look at learning only from the point of view of foreign language or culture, we do not question our own language(s) or culture(s), behaviour or values. If we are working with the languages and cultures we already know, using the previous knowledge we possess when learning a new language and culture, and mirroring back and forth the different concepts and word meanings, we can not only speed up the learning process, but also acquire a deeper understanding of the new language, culture and society. 
Kinship systems and terminologies reflect society, culture and language use. We need to understand them in order to be able to communicate and function in intercultural situations. Understanding other kinship structures and how they function is part of the learning challenge, which includes acquisition of linguistic and cultural competences. An increasing number of children in this globalised world learn several cultures and languages simultaneously, and they switch codes without much effort. But many more have to learn through literature and studies and gradually become aware of their own and other people's cultural patterns. This is no easy process, especially if they have had scarcely any experience of other languages and cultures in their childhood. Tools and instruments are needed. Studying kinship terminology and the linguistic, cultural, social and cognitive processes and connotations connected to the terminology can be a way to facilitate and support the multilingual and multicultural learning. This can have a serious impact on the new relationships we build in a different culture and how well we function as interpreters and cultural ambassadors.

\section{References:}

Banks, James A. (ed.) The Routledge International Companion to Multicultural Education. New York: Routledge, 2009.

Berggren, Henrik and Lars Trägårdh, "Pippi Longstocking: The Autonomous Child and the Moral Logic of Swedish Welfare State", in Swedish Modernism: Architecture, Consumption and the Welfare State. Ed. H. Mattsson and S-O. Wallenstein. London: Black Dog Publishing, 2010: 50-65.

Berggren, Henrik \& Lars Trägårdh, "Social Trust and Radical Individualism. The Paradox at the Heart of Nordic Capitalism". In The Nordic Way: Equality, Individuality and Social Trust. Eds. A. Rembe and K. Persson. Stockholm: Swedish Institute, 2012: 13-29. 
Brown, Penelope, "Cognitive Anthropology". In Language, Culture, and Society. Eds. C. Jourdan and Kevin Tuite. Cambridge: Cambridge University Press, 2006: 96-115.

Brunnbauer, Ulf. Unity in Diversity? Historic Family Forms in Southeastern Europe. Historijski Zbornik, god. LXV, br. 1, 2012: 95-148.

D'Andrade, Roy. Cultural meaning systems. In Culture Theory: Essays on Mind, Self, and Emotion. Eds. R. Shweder and R. LeVine. Cambridge: Cambridge, University Press, 1984: 88-119.

D'Andrade, Roy, "A folk model of the mind". In Cultural models in language and thought. Ed. N. Quinn. Cambridge: Cambridge University Press, 1987: 112-150.

Eurostat (European Union) 2019: Foreign language skills statistics https://ec.europa.eu/eurostat/statisticsexplained/index.php?title=Foreign language skills statistics Accessed 13 December 2021

García, Ofelia; Angel M. Y. Lin and Stephen May (eds.). Bilingual and Multilingual Education. Third edition. Cham: Springer, 2017.

Hajdu, Dorijan and Sabira Ståhlberg, "A Fly in Amber? Nordic-Balkan Citizen Diplomacy and Cultural Connections Then and Now", Journal of Baltic And Nordic Studies, Vol. 12 issue. 2 (2020): 7-48.

Hajdu, Dorijan. Pragmatična ekvivalencija izraza sa konotativnim značenjem u švedskom $i$ srpskom jeziku. [Pragmatical equivalence between expressions with connotative meaning in the Swedish and Serbian languages] Universitet Beograd: Filološki fakultet [University of Belgrade: Philological Faculty], 2018.

Hajdu, Dorijan and Jelena Drljević, “Uticaj vladajućih kognitivnih kulturnih modela i vrednosti na uvredljive izraze vezane za figuru majke $u$ švedskom i italijanskom jeziku" [Influence of ruling cognitive cultural models and values on expletives connected to the figure of mother in Swedish and Italian], Komunikacija $i$ kultura online [Communication and Culture Online], god. 9, br. 9 (2018): 59-75.

Henrich, Joseph. The WEIRDest people of the world. New York: Farrar, Straus and Giroux, 2020. 
Henrich, Joseph, Steven J. Heine and Ara Norenzayan, “The weirdest people in the world?" Behavioral And Brain Sciences 33 (2010): 61-135.

Hofstede Insights: country comparison: https://www.hofstedeinsights.com/product/compare-countries/Accessed 13 December 2021

Martin-Jones, Marilyn; Adrian Blackledge and Angela Creese (eds.), The Routledge Handbook of Multilingualism. Oxon/New York: Routledge, 2012.

National Statistical Institute, Bulgaria; marital and extramarital births in Bulgaria in 2020:

https://www.nsi.bg/en/content/2963/marital-and-extra-marital-live-birthsdistricts-municipalities-and-place-residence Accessed 13 December 2021

Språkbruk, Monica Äikäs 2006: Plastfamiljer, umgängesföräldrar och mambor. [Plastic families, socialising parents and those living with Mum] https://www.sprakbruk.fi/-/plastfamiljer-umgangesforaldrar-ochmambor Accessed 13 December 2021

Stahlberg, Sabira 2020a. Multicoloured book. Helsingfors/Helsinki: Bokpil.

Stahlberg, Sabira 2020b. Multicoloured language. Helsingfors/Helsinki: Bokpil. Sue, Derald Wing and Lisa Spanierman (eds.). Microaggressions in everyday life. Second Edition, Hoboken: Wiley, 2020.

Svenska Akademiens Ordböcker [Swedish Academy Dictionaries]: https://svenska.se/ Accessed 13 December 2021

Todorova, Maria N. 2006. Balkan family structure and the European pattern. Demographic developments in Ottoman Bulgaria. Budapest: Central European University Press.

Wright, Wayne E.; Sovicheth Boun and Ofelia García (eds.). The Handbook of Bilingual and Multilingual Education. Chichester: Wiley Blackwell, 2015.

\section{Survey}

University of Belgrade, April 2021 